Acta vet. scand. $1981,22,360-368$.

From the Department of Pharmacology and Toxicology and the Ambulatory Clinic, College of Veterinary Medicine, and the State Veterinary Medical Institute, Helsinki, Finland.

\title{
MILK ANTITRYPSIN ACTIVITY DURING CLINICAL AND EXPERIMENTAL BOVINE MASTITIS
}

\author{
By \\ T. Honkanen-Buzalski, T. Katila and M. Sandholm
}

\begin{abstract}
HONKANEN-BUZALSKI, T., T. KATILA and M. SANDHOLM: Milk antitrypsin activity during clinical and experimental bovine mastitis. Acta vet. scand. 1981, 22, 360-368. - Milk trypsin-inhibitor levels were followed during clinical and experimental endotoxin-induced mastitis. Milk trypsin-inhibitor level proved to be a good indicator of mastitis, closely relating to milk BSA values. The trypsin-inhibitor pattern in the quarter milk samples during mastitis closely resembled the pattern of BSA, which indicates that the trypsin-inhibitor is blood derived and diffuses to the mammary gland like albumin. The timing of the increase in the trypsin-inhibitor into the endotoxin infused quarter closely matched with the increase in body temperature, heart rate, decrease in blood leucocytes and increase in somatic cells. Serum zinc and iron showed a decrease a few hours later.
\end{abstract}

trypsin-inhibitors; proteinase inhibitors; bovine mastitis; milk; milk proteins; somatic cell count; antitrypsin; endotoxin; serum zinc; serum iron; bovine serum albumin.

Proteolytic enzymes are known to be released at the site of inflammation subjecting the surrounding tissue to self-digestion. The significance of proteinase inhibitors preventing self-digestion by endogenous proteinases was realized when it was established that a deficiency of $\alpha_{1}$-antitrypsin represented a high risk for pulmonary emphysema in man (Ganrot et al. 1967). The pathogenetic mechanism of this disease is an autodigestive destruction of lung tissue by proteinases from leucocytes (Mittman 1972).

Many mastitic pathogens are known to secrete proteolytic enzymes. However, much of the proteolytic activity at the inflammation site is known to originate from the phagocytes 
(Weissmann et al. 1979). A heavy invasion of polymorphonuclear leucocytes (PMN) from the blood to the milk alveoli is characteristic for bovine mastitis. These leucocytes release proteolytic enzymes and subject the mammary gland tissue to self-digestion.

We recently described how protection by antitrypsin is operating in the udder: mastitic milk contained increased amounts of protease inhibitors. The trypsin-inhibitor capacity was seen to be correlated with the somatic cell count and albumin (BSA) in milk. The trypsin-inhibitor capacity in mastitic milk was traced primarily to an albumin-size molecule. These molecules were bigger than inhibitors present in colostrum. The albuminsize antitrypsin, which is dominating in bovine serum and mastitic milk, should be considered analogous with human $\alpha_{1}$-antitrypsin although no immunological cross-reactivity could be seen. This antitrypsin showed electrophoretic heterogeneity which is probably due to the presence of different phenotypes (Honkanen-Buzalski \& Sandholm 1981).

The present investigation was carried out to study the antitrypsin activities during different stages of bovine mastitis. The antitrypsin level was correlated with other mastitis markers such as body temperature, heart rate, bacteriology, somatic cell count, albumin and serum zinc and iron contents. From this information it was possible to determine how the proteinase inhibitor system in the cow reacts in mastitis. The value of antitrypsin determination as an indicator of mastitis at the different stages of the disease could also be followed.

\section{MATERIALS AND METHODS}

\section{Clinical mastitis}

Six Ayrshire cows with acute mastitis were selected from the daily material at the Ambulatory Clinic, College of Veterinary Medicine, Finland. Quarter milk and serum samples were collected daily during the first 4 days and frequently thereafter during 1 month.

The cows were treated using a single intramuscular injection of penicillin-streptomycin preparation $\left(50 \mathrm{ml}\right.$ Combiotic ${ }^{\circledR}$, Pfizer) and daily intramammary treatment of the same combination for 4 days (Streptomax ${ }^{\circledR}$, Lääke). The quarter milk samples taken before any treatment were analyzed by conventional bacteriology. To confirm the recovery, bacteriology on quarter milk 
samples was repeated 1 and 2 months later. Trypsin-inhibitor capacity and albumin levels were determined from all the consecutive milk and serum samples.

\section{Experimental mastitis}

Endotoxin-induced mastitis was produced by intramammary infusion on 2 Ayrshire cows following the method used by Verheijden et al. (1981). Endotoxin, (0.1 mg LPS from E. coli 0111, B4, Difco Laboratories) was dissolved in $20 \mathrm{ml} 0.9 \%$ saline. After being sterilized by filtration (filter pore size $0.45 \mu \mathrm{m}$ ) the pyrogen was infused into the left rear teat. Body temperature and heart rate were monitored continuously. Blood and milk samples were drawn 1 hour before and immediately prior to pyrogen infusion followed by hourly samplings. After $12 \mathrm{~h}$ the sampling interval was gradually increased, the last sampling being at $72 \mathrm{~h}$.

\section{Blood and milk parameters}

The trypsin-inhibitor capacity was measured by mixing the sample (serum and milk) with trypsin in different ratios followed by measurement of the excess trypsin by enzyme diffusion in an agar-gel containing rennet-precipitated casein (Sandholm \& Honkanen-Buzalski 1979). The albumin content of the same samples were determined by radial immunodiffusion (Mancini et al. 1965). Diffusion plates were prepared having a $2 \mathrm{~mm}$ thick gel layer containing $1 \%(\mathrm{w} / \mathrm{v})$ purified agar (Difco) and $5 \%$ (v/v) of swine anti-bovine albumin in $0.02 \mathrm{~mol} / \mathrm{l}$ Veronal buffer, $\mathrm{pH}$ 8.6. Wells of $6 \mathrm{~mm}$ diameter were cut and $50 \mu \mathrm{l}$ of each sample were transferred into them and the diameter of the resulting zone was measured after $72 \mathrm{~h}$ diffusion using an overhead projector (enlargement $100 \times$ ). The BSA concentration was extrapolated from a standard curve obtained from pure BSA-solutions $(6,3,1.5, \ldots \mathrm{mg}$ albumin $/ \mathrm{ml})$. The serum zinc content was determined by atomic absorbtion spectrophotometry (Perkin Elmer 5000 AAS) after diluting the samples in a ratio 1:5 in twice distilled and deionized water. Serum iron was determined after dry-ashing by a colorimetric method using $2,4,6$-tripyridyl-s-triazine as a reagent for iron (Collins et al. 1959). Blood total white cell counts were determined from EDTA-anticoagulated samples by a haemocytometric technique and differential white cell counting performed on stained blood smears. Somatic 
cell counts in quarter milk samples were determined by the Coulter counter chemical method (Tolle et al. 1966).

\section{RESULTS}

Follow-up studies on mastitis cows showed that the trypsininhibitor capacity and albumin levels were high in the infected quarters and were normalized at about 20 days in the cows which recovered (negative bacteriology at 1 month and 2 months). Results of one of these 2 cows are shown in Fig. 1 (cow A), but 4 of the cows which did not recover completely (positive bacteriology either at 1 month or 2 months) showed high trypsininhibitor and albumin levels during the whole follow-up period (Fig. 1, cow B).

Endotoxin-induced mastitis in both cows showed the same general pattern as described by Verheijden et al. (1981), (Fig. 2): body temperature rapidly increased reaching maximum at $6 \mathrm{~h}$ after infusion and the heart rate reached maximum at about the same time. Transient leucopenia associated with an increase in somatic cells in the infused quarter was obvious. Serum zinc and iron levels decreased rapidly in parallel $8 \mathrm{~h}$ post infusion. The trypsin-inhibitor capacity and BSA in the infused quarters started to increase between 1 and $2 \mathrm{~h}$ after the infusion, and was at the maximum at 3 and $6 \mathrm{~h}$; these values gradually declined, normalizing after about $50 \mathrm{~h}$. The shapes of the trypsin-inhibitor and albumin curves closely mimic each other (Fig. 2). In both cows a slight increase in trypsin-inhibitor and BSA were seen in the front teats of the left side but not in the teats on the right side (LR infused). The timing of the increase in the trypsininhibitor capacity and BSA closely followed the increase of body temperature and heart rate, decrease in blood leucocytes and an increase in somatic cells. Serum zinc and iron started to decrease several hours later (Fig. 2).

\section{DISCUSSION}

The infiltration of leucocytes into the mammary gland is known to play a significant protective role against mastitic pathogens. The major cell type contributing to elevated somatic cell counts is the neutrophil leucocyte (Schalm et al. 1971). Polymorphonuclear granulocytes are known to release proteolytic activity at the inflammatory site (Weissmann et al. 1979). Some proteolytic activity may also originate from the pathogens as 

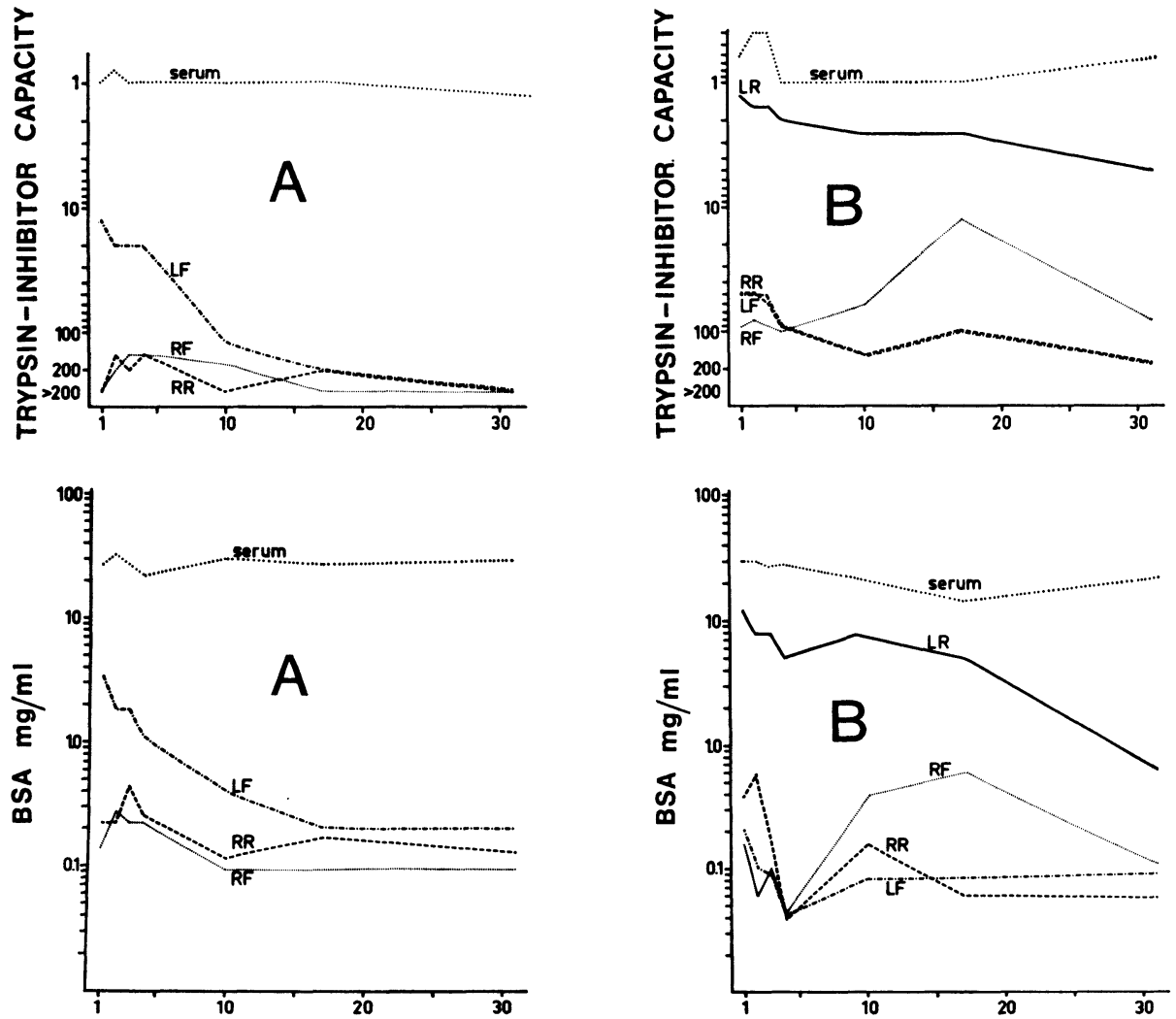

\section{TIME (DAYS)}

Fig u re 1. Follow-up analysis of serum and milk trypsin-inhibitor levels and respective albumin levels in 2 cows (A and B) with acute mastitis.

Cow A had mastitis in the left front quarter (LF) (Staphylococcus aureus, left rear quarter was dry). The infection was cleared by antibiotics as confirmed by negative bacteriology at 1 month and 2 months after the outbreak. Note that the trypsin-inhibitor and albumin curves are similarly being normalized at 20 days.

The leaf rear quarter (LR) of cow B was coinfected by Str. dysgalactie and Corynebacterium pyogenes. The infection was not cleared despite treatment with antibiotics. Note that the trypsin-inhibitor level as well as albumin level remained high.

The trypsin-inhibitor capacity is given in $\mathrm{ml}$ of milk required to inactivate $1 \mathrm{mg}$ bovine trypsin. 

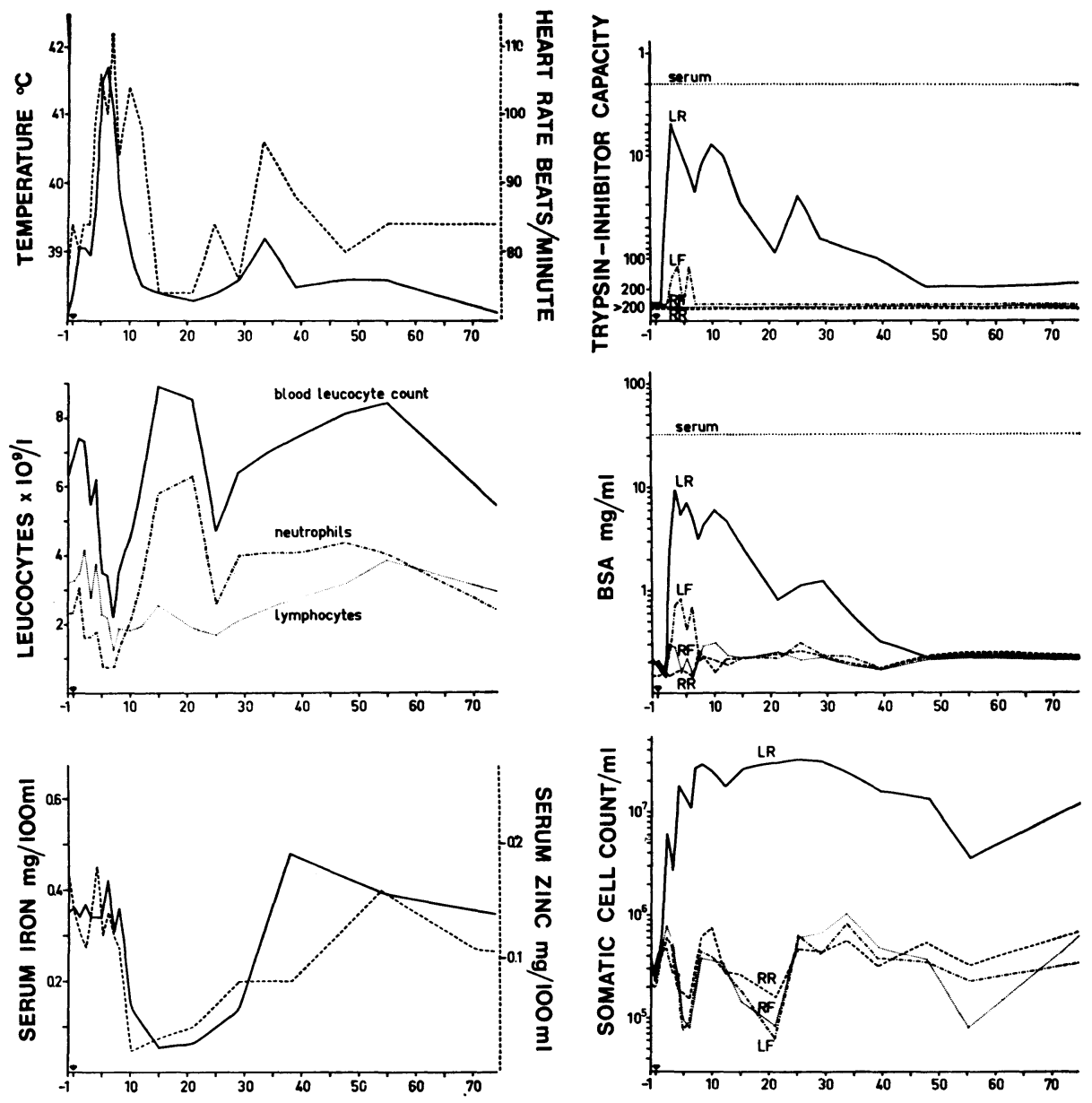

\section{TIME (HOURS)}

F ig u r e 2. Effect of intramammarily administered endotoxin (0.1 $\mathrm{mg}$ ) on body temperature, heart rate, blood leucocytes, serum iron and zinc, serum and quarter-milk trypsin-inhibitor and albumin as well as somatic cell counts. Note that the increased trypsin-inhibitor and albumin levels closely parallel each other. The time of endotoxin injection is indicated by an arrow.

well as from soluble endogenous sources being activated during inflammation (plasmin type). The proteinases obviously subject the mammary gland and milk protein to proteolytic attack.

The proteinase-inhibitors in epithelial secretions are known to inactivate both trypsin and neutral proteinases from leucocytes (Heimburger 1975). This cross-reactivity enables commer- 
cial trypsin to be used in the laboratory measurements to assess the level of protection against endogenous proteinases.

A high correlation between trypsin-inhibitor capacity and somatic cell counts as well as BSA content of milk has been shown (Honkanen-Buzalski \& Sandholm 1981); based on 310 randomly collected milk samples the correlation between trypsin-inhibitor capacity and BSA could be expressed by the formula: $\mathrm{y}=3.31-1.05 \mathrm{x}$ (where $\mathrm{x}=\ln ($ albumin) and $\mathrm{y}=\ln$ (antitrypsin), $r=0.888$. Similarly, the correlation between antitrypsin and somatic cell count gave a formula: $\mathrm{y}=-5.81+$ $1.969 \mathrm{x}-0.085 \mathrm{x}^{2}$ (where $\mathrm{x}=\ln$ (somatic cell count) and $\mathrm{y}=\ln$ (antitrypsin), $r=0.766$ ).

The present investigation confirms that increased trypsininhibitor levels are safe indicators of mastitis. Milk trypsininhibitors seem to be blood derived. Both in clinical mastitis as well as endotoxin induced mastitis the milk BSA and trypsininhibitor concentration closely followed each other. The BSA is known to diffuse from blood to the alveolar space through the separated tight junctions between the endothelial and epithelial cells. The BSA content of milk has been regarded as a sensitive indicator of mastitis (Schalm et al. 1971). As the trypsin-inhibitor content increases concurrently with BSA, a similar transfer mechanism by diffusion is obvious. In all the cows with clinical mastitis the serum trypsin-inhibitor level increased during the first few days indicating that this inhibitor belongs to the "acute phase reactants". This increase in trypsin-inhibitor in the blood compartment supports the previous results as to why trypsininhibitors in milk are increased by a higher factor than albumin during mastitis. The mechanism of the increase in the permeability between blood and milk resulting in leakage of trypsininhibitors and albumin can not be directly answered by this study.

The inflammatory process includes fenestration of the microvasculature, leakage of the elements of blood outside the vasculature and migration of leucocytes into the inflamed tissue. During this complex response, chemical mediators such as histamine, 5-hydroxytryptamine (5-HT), slow-reacting substance (SRS), various chemotactic factors, bradykinin and prostaglandins are liberated locally. Inflammatory material are known to be released from phagocytes when these are exposed to phagocytic stimulus. Lysosomal enzymes escape to the surrounding 
tissue, toxic oxygen products are liberated and plasma membrane fatty acids are transformed by phospholipases into the prostaglandin or lipoxygenase pathways (Weissmann et al. 1979). Leucocytes are known to release endogenous pyrogens leading to fever, and leucocytes release endogenous mediator (LEM) which stimulates the liver to take up zinc and iron as demonstrated with the rat (Pekarek et al. 1972). In an analogy, bovine serum zinc and iron have been seen to decrease after intravenous or intramammary infusion of endotoxin (Verheijden et al. 1981). These zinc and iron parameters were utilized in the present study to confirm the function of the endotoxin in experimental mastitis. Because serum iron and zinc decreased later than antitrypsin leaked into the udder, they do not seem to be directly involved in the fenestration.

It seems logical to assume that the diapedesis of inflammatory cells from blood into the udder somehow determines the transfer of trypsin-inhibitors. It would make sense to obtain protection by proteinase inhibitors at the site where leucocytic proteases are going to be released. However, the trypsin-inhibitor level declined more rapidly after endotoxin induced mastitis than the somatic cell count, indicating that the total amount of somatic cells is not the determinant but a factor released by the leucocytes during acute inflammation.

The present investigation confirms that milk trypsin-inhibitor level is a safe mastitis indicator and it can be used to qualify the success of the treatment. The determination of proteinase inhibitor may become important in the dairy industry because inhibitors present in milk would disturb the processes based on proteolytc manufacturing principles such as rennet coagulation, cheese maturity and youghurt production.

\section{ACKNOWLEDGEMENT}

We thank Anna Salmi, M.S. for analyzing the $\mathrm{Zn}$ and Fe.

\section{REFERENCES}

Collins, P. F., H. Diehl \& G. F. Smith: 2, 4, 6-Tripyridyl-s-triazine as a reagent for iron. Determination of iron in limestone, silicates, and refractories. Anal. Chem. 1959, 31, 1862-1867.

Ganrot, P. O., C-B. Laurell \& S. Eriksson: Obstructive lung disease and trypsin inhibitors in $\alpha_{1}$-antitrypsin deficiency. Scand. J. clin. Lab. Invest. 1967, 19, 205-208.

Heimburger, N.: Proteases and Biological Control. ed. Reich, E., D. B. Rifkin \& E. Shaw. Cold Spring Harbor Laboratory 1975, p. $367-386$. 
Honkanen-Buzalski, T. \& M. Sandholm: Trypsin-inhibitors in mastitic milk and colostrum: correlation between trypsin-inhibitor capacity, bovine serum albumin and somatic cell contents. J. Dairy Res. 1981, 48, 213-223.

Mancini, G., A. O. Carbonara \& J. F. Heremans: Immunochemical quantitation of antigens by single radial immunodiffusion. Immunochemistry 1965, 2, 235-254.

Mittmann, C.: Pulmonary Emphysema and Proteolysis. Academic Press, New York, London 1972, p. 1.

Pekarek, R. S., R. W. Jr. Wannemacher \& W. R. Beisel: The effect of leukocytic endogenous mediator (LEM) on the tissue distribution of zinc and iron. Proc. Soc. exp. Biol. Med. 1972, 140, $685-688$.

Sandholm, M. \& T. Honkanen-Buzalski: Colostral tryptin-inhibitor capacity in different animal species. Acta vet. scand. 1979, 20, $469-476$.

Schalm, O. W., E. J. Carrol \& N. C. Jain: Bovine Mastitis. Lea \& Febiger. Philadelphia 1971, p. 1.

Tolle, A., H. Zeidler \& W. Heeschen: Ein Verfahren zur elektronischen Zählung von Milchzellen. (A method of electronic cell count in milk). Milchwissenschaft 1966, 21, 93-98.

Weissmann, G., H. E. Korchak, H. D. Perez, J. E. Smolen, I. M. Goldstein \& S. T. Hoffstein: Advances in Inflammation Research 1. Raven Press, New York 1979, p. 95-112.

Verheijden, J. H. M., A. S. J. A. M. van Miert, A. J. H. Schotman \& C. T. $M$. van Duin: Plasma zinc and iron concentrations as parameters for evaluating the influence of endotoxin - neutralizing agents in E. coli - endotoxin induced mastitis. 1981 (in press).

\section{SAMMANFATTNING}

Antitrypsinaktivitet $i$ mjölk vid kliniska och experimentella mastiter.

Mjölkets trypsin-inhibitorkapacitet analyserades vid kliniska och experimentella endotoxin-inducerade mastiter. Trypsin-inhibitorkapacitet synes vara en bra mastit-indikator av liknande värde, som en bestämning av mjölkets albumin (BSA).

Vid en longitudinell undersökning av mastitkor visade antitrypsinaktiviteten och albuminmängden en överstämmande korrelation, vilket indikerar att trypsin-inhibitorerna diffunderar från blodet på samma sätt som BSA.

Vid endotoxin inducerad mastit blev mjölkets trypsin-inhibitorhalt maximalt nästan samtidigt med ökningen av temperaturen, pulsen och mjölkets cellhalt. Zink- och järnhalten i serum sjönk efter några timmar.

(Received May 13, 1981).

Reprints may be requested from: M. Sandholm, the Department of Pharmacology and Toxicology, College of Veterinary Medicine, P.O. Box 6, SF-00551 Helsinki 55, Finland. 